\title{
Erratum to: From methylene blue to chloroquine: A brief review of the development of an antimalarial therapy
}

\section{Kristine Krafts • Ernst Hempelmann • Agnieszka Skórska-Stania}

Published online: 8 May 2012

(C) Springer-Verlag 2012

Erratum to: Parasitol Res.

DOI 10.1007/s00436-012-2886-x

The original version of this article inadvertently contained a mistake.

The word "mecaprine" should be read as "mepacrine" while the Hebrew name should be read as "יהוחנן" not as "מחנ" "

The online version of the original article can be found at http://dx.doi.org/ 10.1007/s00436-012-2886-x.

K. Krafts $(\bowtie)$

Department of Pathology,

University of Minnesota School of Medicine,

Duluth, MN, USA

e-mail: kristinekrafts@gmail.com

E. Hempelmann

Department of Pharmacology, Witwatersrand University,

Johannesburg, South Africa

\section{A. Skórska-Stania}

Department of Crystal Physics and Crystal Chemistry,

Faculty of Chemistry, Jagiellonian University,

Kraków, Poland 